\title{
PEMBERDAYAAN SANTRI PESANTREN BERWAWASAN \\ KEAHLIAN, KETERAMPILAN, DAN KEMAMPUAN SOFT SKILL DI PROVINSI BENGKULU
}

\section{EMPOWERMENT OF PESANTREN STUDENT IN AWARNESS OF EKSPERTISE, SKILLS, AND SOFT SKILL IN THE PROVINCE OF BENGKULU}

\author{
Oleh: \\ ${ }^{1}$ Basuki Sigit Priyono, ${ }^{1}$ Eko Sumartono, ${ }^{1}$ Apri Andani, ${ }^{2}$ Ferzha Putra Utama \\ ${ }^{1}$ Program Studi Agribisnis Jurusan Sosial Ekonomi Pertanian Fakultas Pertanian dan \\ ${ }^{2}$ Program Studi Teknik Informatika Fakultas Teknik \\ Universitas Bengkulu \\ Email:eko_vixion@unib.ac.id
}

\begin{abstract}
Pesantren, one of the containers and education community, is still considered less promising quality of general education for example in the form of appropriate technology and information technology. Technology misuse can indeed endanger the development of students, but if gives direction and carefully supervised by educators, of course technological developments can provide a soft skill that can be used by students after completing education from pesantren. Students in pesantren have a potential to be given material about the introduction of technology in various sciences and basic computer applications. The aim is the students are not surprised by the demands of post-pesantren technology as has been done by providing training on basic computer applications and the use of e-libraries. In addition, appropriate technology in the field of agriculture and fisheries is also transmitted to students to create a fish pond combined with aquaponic vegetation, such as vegetables. KKN program has provided many benefits related to learning and community empowerment. University of Bengkulu (UNIB), the nearest state university of pesantren, implement this KKN-PPM program through students from various disciplines and has been totally implemented in three pesantren and Bengkulu, such as AlHasanah, Hidayatullah, and Pancasila.
\end{abstract}

Keywords: students, appropriate technology, pesantren, softskill

\section{PENDAHULUAN}

Pesantren adalah sebuah lembaga pendidikan Islam tradisional untuk mempelajari, memahami, menghayati dan mengamalkan ajaran agama Islam dengan menekankan pentingnya moral keagamaan sebagai pedoman perilaku sehari-hari. Pengertian ini dapat dikatakan lengkap apabila di dalam pesantren itu terdapat elemen-elemen seperti pondok, masjid, kyai (pimpinan/guru) dan pengajaran kitab-kitab klasik. Potret pesantren pada dasarnya adalah sebuah asrama pendidikan Islam tradisional dimana para siswanya tinggal bersama dan belajar ilmu-ilmu keagamaan di bawah bimbingan guru yang lebih dikenal dengan sebutan kyai (Mastuhu, 1988). Kata santri itu sendiri merupakan gabungan dua suku kata, yaitu sant (manusia baik) dan tra (suka menolong), sehingga kata pesantren 
dapat berarti tempat pendidikan untuk membina manusia menjadi orang baik (Hamid, 1983). Potret Pesantren pada dasarnya adalah sebuah asrama pendidikan Islam tradisional dimana para siswanya tinggal bersama dan belajar ilmu-ilmu keagamaan di bawah bimbingan guru yang lebih dikenal dengan sebutan kyai (Mastuhu, 1988).

Wahid (1998) memaknai pesantren secara teknis sebagai a place where santri (student) live (dalam Ooepen and Karcher, 1998). Mas'ud (1998) menulis, the word pesantren stems from 'santri' which means one who seeks Islamic knowledge. Usually the word pesantren refers to a place where the santri devotes most of his or her time to live in and acquire knowledge. Masih banyak lagi para peneliti yang memberikan pengertian tersendiri tentang pesantren berdasarkan konteks pemahaman dan sudut pandangnya masing-masing.

Sebatas pemahaman kita selama ini, ada 3 (tiga) elemen yang membuat pesantren mampu menjadi sub-kultur tersendiri, (Munir, 2011) yaitu:

1. Pola kepemimpinan yang mandiri dan tidak terkooptasi kepentingan-kepentingan berjangka pendek. Elemen ini sungguh sangat penting bagi pesantren. Artinya, atasan seorang kiai (pimpinan pesantren) itu hanyalah Allah. Tidak ada kelompok politik, aparatur negara, birokrat, atau manusia lain, yang bisa mengintervensi terlalu jauh di dunia pesantren. Pola kepemimpinan seperti itu membuat pesantren menjadi unik.

2. Kitab-kitab rujukan yang digunakan di banyak pesantren, umumnya terdiri dari warisan peradaban Islam dari berbagai abad. Kalau itu dikaji betul, pengetahuan yang akan diserap para santri pesantren akan sangat luas sekali. Dari situ mereka tidak hanya belajar bagian fikih yang rigid, sempit, kaku, hitam-putih (kitab kuning), dan halalharam saja, tapi juga ilmu-ilmu ushul fikih, ilmu kalam, tasawuf, dan lain-lain. Semua itu menunjukkan kearifan dan keindahan Islam. Mestinya itu akan membentuk wawasan keislaman yang padu dan utuh bagi santri, karena mereka mendalami agama tidak sekadar pilihan hitam-putih yang nampak di permukaan.

3. Sistem nilai atau values system yang diterapkan di pesantren itu sendiri. Sistem nilai itulah yang nantinya akan dibawa dalam proses kehidupan mereka di masyarakat. Di sini kita mengenal nilai-nilai dasar pesantren, seperti al-ushûl khamsah (lima prinsip dasar) yang diadopsi dari paham Ahli Sunnah. Nilai-nilai dasar tersebut adalah: Tawâsuth, tidak memihak atau moderasi, Tawâzun, menjaga keseimbangan dan harmoni, Tasâmuh, Toleransi, Sikap adil dan Tasyâwur.

Bahkan ada segilintir kelompok menusia yang mengatakan pesantren sebagai bagian dari kamuflase kehidupan, alasannya karena pesantren lebih banyak mengurusi urusan ukhrawiyah dibandingkan dengan urusan duniawiyah. Pesantren sering dilabelkan sebagai pusat kehidupan fatalis, karena memprioritaskan dan menanamkan kehidupan zuhud yang mengabaikan kehidupan dunia materi. Padahal, komunitas pesantren menikmati kesederhanaan kehidupannya sebagai bagian dari panggilan moralitas keberagamaan (Depdiknas, 2007).

Prinsip musyawarah Dari keterangan sederhana ini saja kita dapat menarik garis linear tentang apa peranan pesantren dan dimana letak pendidikan pesantren dalam masyarakat Indonesia merdeka. Untuk bangsa yang lebih berkepribadian.Gambaran konkretnya dapat dianalogikan sebuah pesantren Indonesia (ambil sebagai misal Tebuireng di Jombang) sebagai sebuah kelanjutan pesantren di Amerika Serikat (ambil sebagai missal "pesantren" yang didirikan oleh pendeta Harvard di dekat Boston). Tebuireng menghasilkan apa yang dapat dilihat oleh bangsa Indonesia sekarang ini, dan pesantrennya Pendeta Harvard telah tumbuh menjadi universitas yang paling prestigious di Amerika modern (Madjid, 1997). 
Kini di tengah-tengah sistem Pendidikan Nasional yang selalu berubah-ubah dalam jeda waktu yang tidak lama, apresiasi masyarakat Islam Indonesia terhadap pesantren makin hari makin besar, pesantren yang asalnya sebagai Rural Based Institution kemudian berkembang menjadi lembaga pendidikan urban. Di Provinsi Bengkulu terdaftar 49 pesantren, misalnya pondok pesantren Pancasila di Kota Bengkulu adalah pondok pesantren tertua, namun sejumlah pesantren mulai bermunculan seperti pondok pesantren Al Hasanah di Bengkulu Tengah, pondok pesantren Hidayahtullah di Kota Bengkulu, serta masih banyak lagi pesantren lainnya.

Pada program pengabdian di pesantren ini mahasiswa UNIB mengikuti pola hidup santri di pesantren, yaitu dengan menginap di asrama bersama santri mulai tanggal 12 Juni26 Agustus. Kemudian dapat menyampaikan materi saat jam belajar santri dengan didampingi oleh guru yang ada di pesantren, bahkan di luar jam belajar pesantren serta dikontrol secara rutin oleh Dosen Pembimbing Lapangan (DPL).

\section{METODE PENGABDIAN}

Dalam pengabdian masyarakat ini, kelompok sasaran adalah santri di tiga pondok pesantren di Provinsi Bengkulu yaitu Pancasila, Hidayatullah, dan Al-Hasanah. Terdapat tiga tahap dalam mendukung program ini yaitu:

1. Persiapan dan pembekalan

Persiapan yang dilakukan dimulai dengan survey lokasi pendahuluan dan program kerja riil mahasiswa yang mungkin bisa dilakukan. Seleksi mahasiswa akan diadakan pada bulan Mei 2017, dengan indikator- indikator calon peserta disesuaikan dengan lingkungan pesantren. Melihat sasaran dari kegiatan ini adalah pesantren maka peserta harus beragama Islam. Pelaksanaan pembekalan akan dilakukan di bulan Juni 2017 dan tahun berjalan atau 2 (dua) minggu sebelum dilakukan pelaksanaan KKN PPM. Kebutuhan tepat guna santri mencakup pembelajaran di bidang sastra dan budaya, teknologi informasi, teknologi pertanian dan aplikasinya, pengetahuan mesin dan teknologi perikanan serta pembelajaraan yang sifatnya terpadu.

2. Pelaksanaan

Pelaksanaan kegiatan KKN-PPM di Pesantren Al-Hasanah, Hidayahtullah dan Pancasila dilakukan pada awal bulan Juli 2017 sampai pertengahan bulan Agustus 2017. Pelaksanaan KKN-PPM ini akan dimulai dengan tahap pengenalan lingkungan, identifikasi permasalahan secara mendalam (lokakarya) bersama-sama dengan pengurus dan manajemen pesantren, kemudian dilanjutkan dengan pembelajaran/ penyuluhan, pendampingan kegiatan baik teori maupun praktik, monitoring kegiatan, dan evaluasi di akhir kegiatan.

3. Rencana keberlanjutan program

Keberlanjutan program KKN-PPM sangat bergantung pada aspek sumberdaya manusia yang ada baik dari segi peserta KKN-PPM maupun santri yang dapat menerima masukan dari KKN-PPM. Disamping itu lokasi yang dekat dengan UNIB maka dapat memberikan efektivitas keberlangsungan program KKN-PPM ini, sehingga mampu termonitoring dengan baik. Kegiatan KKN-PPM ini akan dilanjutkan pada tahun ke-2 dan tahun ke-3 berdasarkan evaluasi dari tahun sebelumnya. 


\section{HASIL DAN PEMBAHASAN}

\section{Gambaran pelaksanaan kegiatan}

Kegiatan KKN UNIB periode 82 tahun 2017 di keempat pesantren yaitu Pesantren Pancasila Kota Bengkulu, Pesantren Hidayahtullah Kota Bengkulu, Pesantren Hidayahtullah Kab. Rejang Lebong dan Pesantren Al-Hasanah Kab. Bengkulu Tengah telah dilaksanakan pada tanggal 12 Juli 2017 sampai dengan 26 Agustus 2017, walaupun dalam pelaksanaannya terdapat hambatan-hambatan namun secara garis besar program kerja dari kegiatan KKN dapat diselesaikan dengan baik. Adapun hambatan-hambatan yang ditemui dalam pelaksanaan kegiatan program kerja yang telah direncanakan pada umumnya yang berhubungan langsung dengan santri dan pengurus pondok pesantren, seperti kegiatan-kegiatan penyuluhan atau sosialisai. Adapun solusinya adalah mencocokkan waktu sesuai dengan waktu luang yang dimiliki para santri dan pengurus yayasan sehingga santri bisa menghadiri kegiatan, yaitu pada malam siang hari dan selang waktu mereka beristirahat.

\section{Realisasi kegiatan}

A. Pesantren Hidayatullah

1) Pemanfaatan air kolam lele untuk tanaman sayuran dengan menggunakan sistem aquaponik sederhana di Pesantren Al-Hasanah. Waktu pelaksanaan mulai dari 21 Juli s.d. 12 Agustus 2017. Tahapan yang dilaksanakan adalah membuat modul sebagai panduan, sosialisasi, persiapan alat dan bahan, percobaan dan penanaman benih kangkung. Hasil yang didapat adalah modul, sosialisasi kepada santri, dan praktik lapangan.

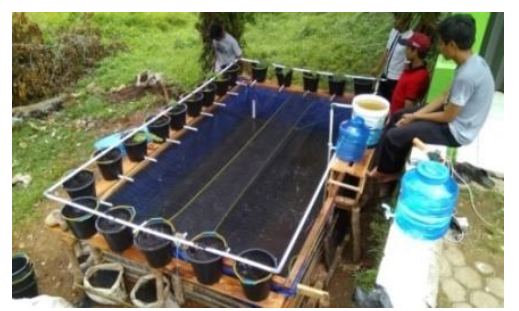

Gambar 1. Pemanfaatan air kolam lele untuk tanaman sayuran dengan menggunakan sistem aquaponik sederhana

2) Sosialisasi kenakalan remaja dan penyalahgunaan narkoba. Waktu pelaksanaan dari 21 s.d. 25 Juli 2017. Tahapan yang dilakukan adalah dengan membuat modul, materi presentasi dan tempat. Hasil yang didapatkan adalah mengerti bahaya narkoba.

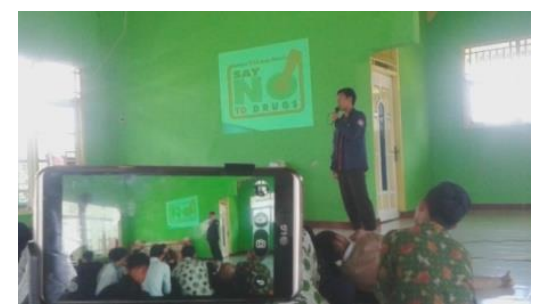

Gambar 2. Sosialisasi kenakalan remaja dan penyalahgunaan narkoba 
3) Pembuatan pupuk kompos menggunakan sampah dapur dengan tambahan EM4. Waktu pelaksanaan dari 22 Juli s.d. 5 Agustus 2017. Tahapan yang dilakukan adalah pembuatan modul, sosialisasi penyuluhan lingkungan bersih, praktik lapangan. Sedangkan hasilnya adalah santri dapat membedakan sampah organik dan anorganik, santri memahami membuat pupuk kompos dan berperilaku hidup bersih.

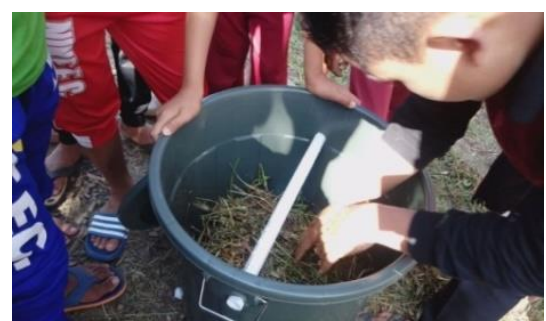

Gambar 3. Pembuatan pupuk kompos menggunakan sampah dapur dengan tambahan EM4

4) Pengolahan ubi jalar menjadi ubi krenyes. Waktu kegiatan dimulai dari 19 Juli s.d. 20 Agustus 2017. Tahapan yang dilakukan adalah membuat panduan, sosialisasi, menyiapkan alat dan bahan, pelatihan dan praktik langsung pada santri, pengemasan dan pelabelan. Hasil yang didapat adalah ilmu pengetahuan bagi santri dan produk siap jual.

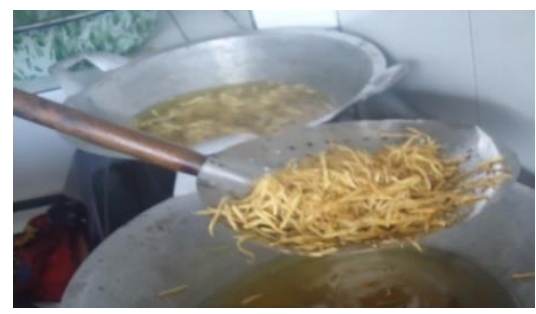

Gambar 4. Pembuatan ubi krenyes

5) Lampu jalan berbasis solar cell dan kendali microcontroller sederhana. Waktu pelaksanaan program kerja dari 29 Juli s.d. 15 Agustus 2017 di Kampus Hidaytullah Curup. Tahapan yang dilakukan adalah pembuatan panduan, sosialisasi program kerja, alat dan bahan, pembuatan tiang lampu, perakitan lampu, instalasi pada lokasi dan pengujian. Hasil yang didapat adalah penerangan yang telah terinstal dan tahan hingga 7 jam.

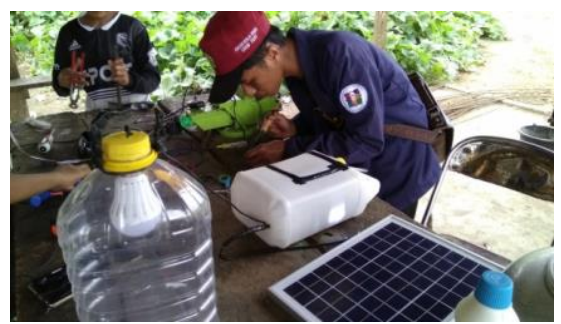

Gambar 5. Pembuatan lampu jalan berbasis solar cell 
6) Pengenalan dan pelatihan Microsoft Word. Waktu pelaksanaan dari 23 Juli s.d. 15 Agustus 2017. Adapun tahapan yang dilakukan adalah pembuatan modul, sosialisasi, pelatihan rutin setiap minggu. Hasil yang diperoleh adalah minat yang tinggi dari santri untuk belajar dan mengembangkan kemampuan pada aplikasi pengolahan kata, Ms. Word.

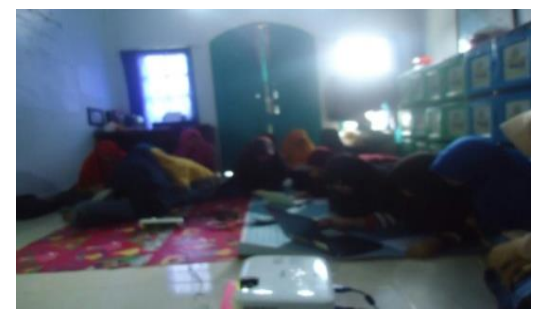

Gambar 6. Pengenalan dan pelatihan Ms. Word

7) Budidaya ikan lele dengan media terpal dilakukan mulai 21 Juli s.d. 21 Agustus 2017. Tahapan yang dilakukan adalah pembuatan modul, sosialisasi, alat dan bahan, pembuatan kolam dengan media terpal, penebaran bibit lele. Adapun hasil yang didapatkan adalah kolam lele yang telah berisi ikan lele dan santri mengerti mengenai budidaya lele.

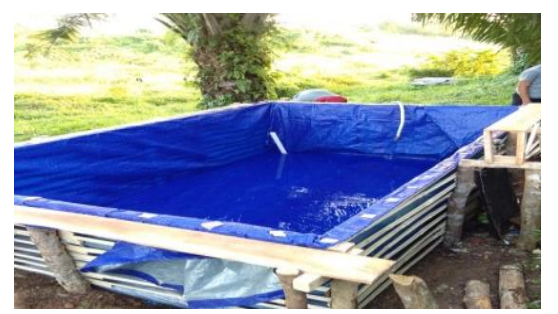

Gambar 7. Budidaya ikan lele dengan media terpal

B. Pesantren Pancasila

1) Penyuluhan hidup sehat dan screening kesehatan dilakukan pada 16 s.d. 17 Juli 2017. Tahapan yang dilakukan adalah perencanaan, izin dari pesantren, pemasangan spanduk kegiatan, dan pelaksanaan penyuluhan. Adapun hasil yang diperoleh adalah penyuluhan, mengontrol dan memberikan solusi dari kebersihan dan masalah kesehatan pada setiap asrama, dan memberikan layanan gratis kepada guru, pengawas, santri untuk screening kesehatan.

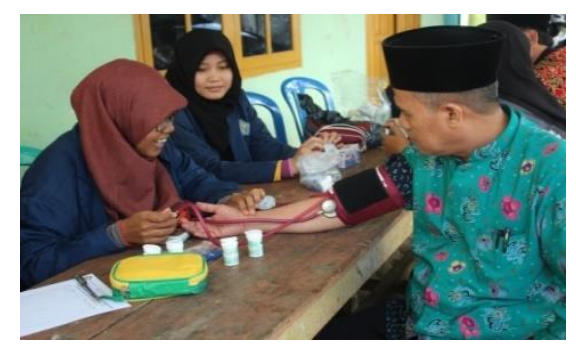

Gambar 8. Screening kesehatan pada guru 
2) Budidaya ikan lele dengan media terpal yang dilakukan dari 20 Juli s.d. 26 Agusus 2017. Tahapan yang dilakukan adalah persiapan kolam, penebaran benih ikan, pemberian pakan, penyortiran ukuran ikan, pengelolaan air dan panen. Hasil yang didapatkan adalah 2 buah kolam berukuran $4 \times 2$ m dan 1 buah kolam berukuran 4x1 m, benih ikan berukuran 3-5 cm dan diberi pakan 3x sehari dengan jenis pakan Pf 500, panen belum dilakukan selama program KKN berlangsung, membutuhkan 3-4 bulan untuk masa panen.

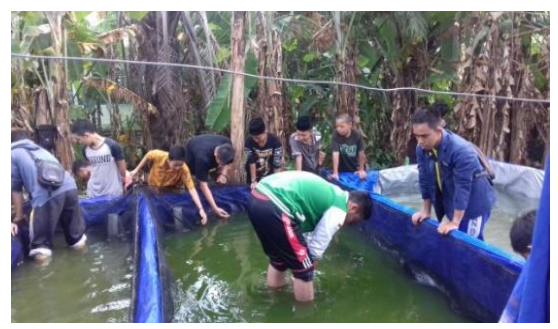

Gambar 9. Budidaya ikan lele

3) Budidaya nanas dan sayur dilakukan mulai 28 Juli s.d. 24 Agustus 2017. Tahapan yang dilakukan adalah membuat modul, sosialisasi program kerja, alat dan bahan, pemilihan lahan, pemupukan lahan, dan penanaman benih. Hasil yang diperoleh adalah penanaman nanas dan sayuran jenis kangkung, terung ungu, dan cabai yang ditanam dengan memanfaatkan lahan rawa dan nanas ditanam pada lahan miring.

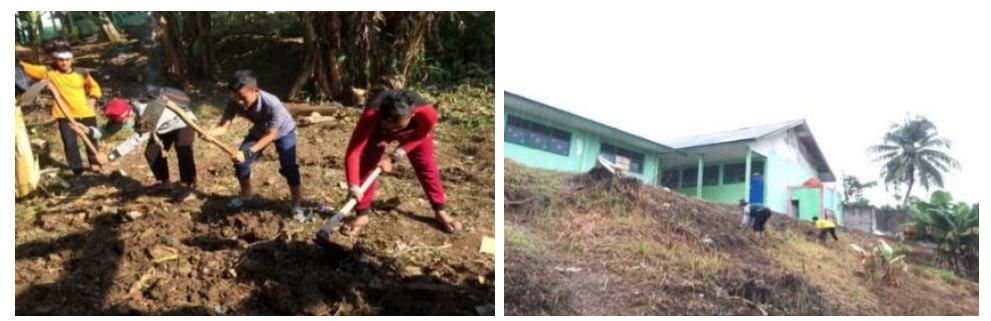

Gambar 10. Budidaya nanas dan sayur

4) Hidroponik dan pemanfaatan batang pisang menjadi pupuk cair dilakukan pada 28 Juli s.d. 3 Agustus 2017. Tahapan yang dilakukan adalah pembuatan modul, sosialisasi program kerja, persiapan alat dan bahan, kerangka sistem hidroponik dengan botol, pembuatan pupuk cair, pemberian nutrisi AB MIX pada hidroponik. Hasil yang diperoleh adalah hasil yang cukup maksimal, benih kangkung dan sawi yang di tanam pada media hidroponik tumbuh dengan baik hanya ada sedikit kendala yaitu dari media tanam yang berupa kapas mengakibatkan tanaman sayuran ini kurang subur dan kurang lebat daunnya. Sedangkan, pupuk cair yang dibuat dari limbah batang pisang sangat baik di gunakan setelah pendiaman selama 2 minggu atau lebih. Pupuk cair dari gedebog pisang sangat baik digunakan pada lahan pertanian yang menggunakan media tanam tanah. 

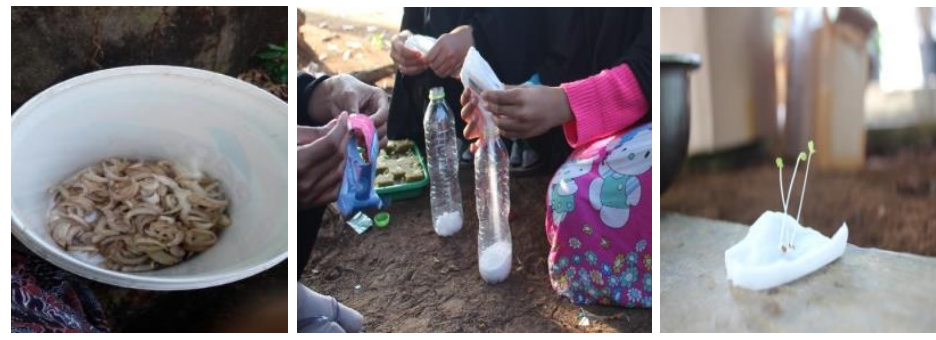

Gambar 11. Hidroponik dan pupuk cair dari batang pisang

5) Pemanfaatan lahan marjinal dan atau pekarangan dengan bertanam sayur menggunakan hidroponik sistem DFT (Deep Flow Technique) dan Wick Sederhana. Waktu pelaksanaan 28 s.d. 30 Juli 2017. Tahapan yang dilakukan adalah membuat modul, persiapan media tanam dan benih, penyemaian, peracikan nutrisi hidroponik, alat dan bahan, instalasi kerangka hidroponik sistem DFT, pemasangan pompa air untuk aliran nutrisi, peletakan pot. Hasil yang diperoleh adalah sistem hidroponik DFT berhasil dilakukan dan tanaman mulai tumbuh.
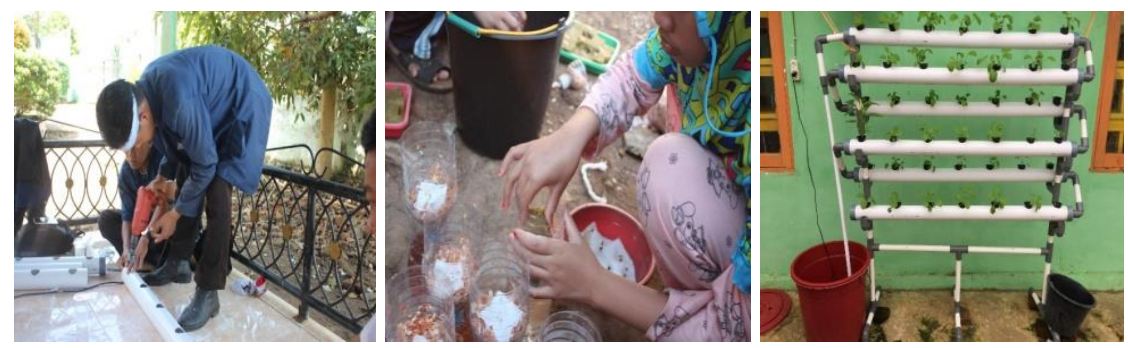

Gambar 12. Hidroponik sistem DFT

6) Pemanfaatan sampah anorganik menjadi bahan bakar minyak (BBM) dilakukan pada 4 Agustus 2017. Tahapan yang dilakukan adalah membuat modul, sosialisasi, alat dan bahan, pengumpulan sampah, alat pengolah sampah anorganik. yang diperoleh adalah berupa bahan bakar minyak yang dapat dimanfaatkan sebagai pengganti minyak tanah.
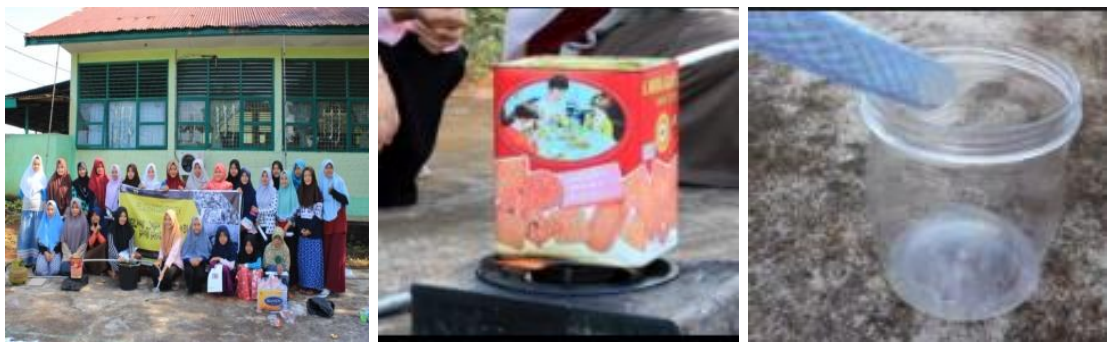

Gambar 13. Penyulingan sampah anorganik menjadi BBM

7) Pelatihan Microsoft Office, desain grafis dan e-katalog. Waktu pelaksanaan 27 Juli s.d. 24 Agustus 2017. Tahapan yang dilakukan adalah pembuatan modul, persiapan materi, praktik langsung, penyusunan buku dan penomoran pada perpustakaan Pesantren Pancasila, pendataan buku, instalasi e-katalog, dan pelatihan e-katalog. Hasil yang dicapai adalah santri dapat mengenal fungsi-fungsi 
yang ada di dalam Ms. Office, mengetahui cara mendesain sticker, dan pengelompokan buku menjadi lebih tertata dan terkomputerisasi.

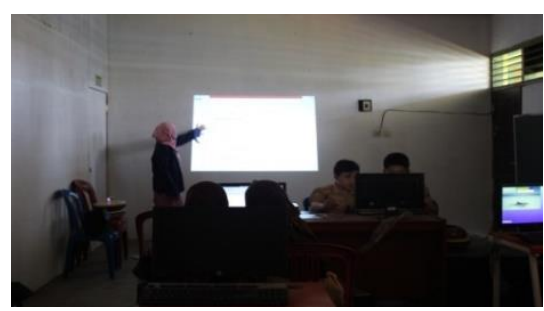

Gambar 14. Pelatihan Ms. Office

8) Pemanfaatan limbah pipa PVC menjadi alat olah raga panahan dilaksanakan pada 10 Agustus 2017. Tahapan yang dilakukan adalah pengumpulan pipa bekas, memotong pipa hingga pada bentuk yang diinginkan, pembuatan busur panah, pembuatan anak panah, percobaan, pelatihan kepada santri. Hasil yang diperoleh adalah meningkatkan nilai guna limbah pipa, menambah kehasanahan sarana olah raga di Pesantren Pancasila.

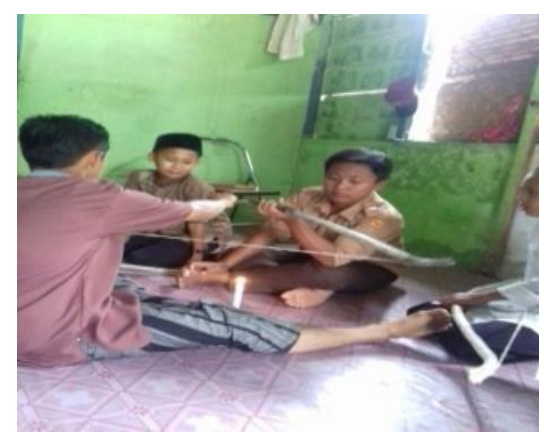

Gambar 15. Panah dari limbah PVC

C. Pesantren Al-Hasanah

1) Budidaya ikan lele dilaksanakan pada 30 Juli s.d. 24 Agustus 2017. Tahapan yang dilakukan adalah pembuatan modul, persiapan kolam, pemilihan benih, penyemaian benih ikan lele, pemberian pakan. Hasil yang diperoleh adalah memberikan pengetahuan dan pelatihan kepada santri tentang budidaya ikan lele.

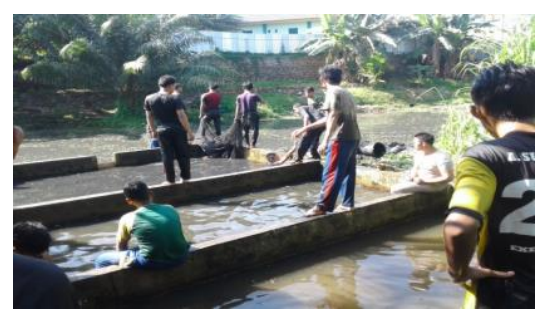

Gambar 16. Budidaya ikan lele

2) Budidaya tanaman holtikultura dengan sistem hidroponik dilakukan setiap minggu dari 7 Agustus s.d. 24 Agustus 2017. Tahapan yang dilakukan adalah pembuatan modul, pelatihan, alat dan bahan dan implementasi. Hasil yang diperoleh adalah 
memberikan pengetahuan dan pelatihan kepada santri dan santriwati tentang manfaat budidaya tanaman holtikultura dengan tanaman pekarangan.

3) Pengolahan nugget dan kripik ikan lele dilakukan 8 s.d. 22 Agustus 2017. Tahapan yang dilakukan adalah pembuatan modul, persiapan alat dan bahan, pelatihan dan sosialisasi, praktik lapangan pada santri, pengemasan dan pelabelan. Hasil yang diperoleh adalah mengedukasi santri dan menghasilkan produk nugget ikan lele dan kripik ikan lele yang bernilai jual tinggi dan rasa yang unik.

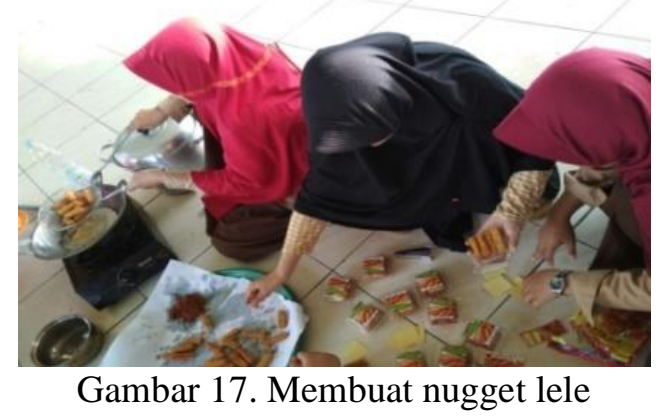

4) Pengolahan jahe susu dan jahe merah instant dilakukan pada 6 dan 18 Agustus 2017.. Tahapan yang dilakukan adalah persiapan alat dan bahan, pembuatan modul, praktik dan sosialisasi pada santri, pengemasan dan pelabelan. Hasil yang diperoleh adalah pengetahuan pembuatan dan pengemasan kepada santri dalam pengolahan jahe menjadi minuman jahe instan.

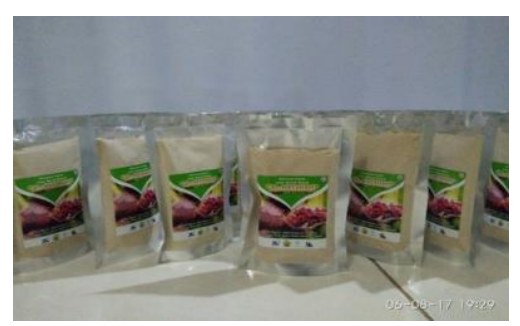

Gambar 18. Produk jahe instan

5) Penyuluhan koperasi syariah dilakukan pada tanggal 19 Agustus 2017. Tahapan yang dilakukan adalah persiapan materi, pemateri, pemasangan spanduk dan pelatihan. Hasil yang didapat adalah memberikan pengetahuan kepada santri, santriwati, dan guru mengenai perbedaan koperasi syari'ah dan koperasi konvensional.

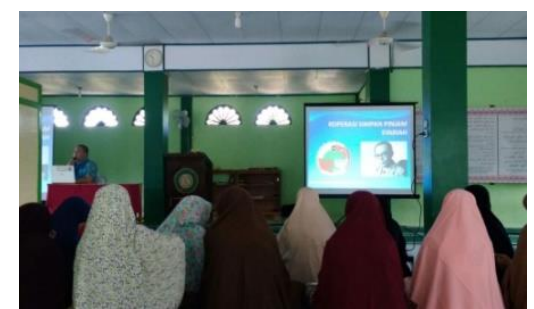

Gambar 19. Pelatihan koperasi syariah pada ustadz dan ustadzah 
6) Screening kesehatan dilakukan pada tanggal 12 Agustus 2017. Tahapan yang dilakukan adalah menyiapkan modul, sosialisasi, pelaksanaan kegiatan screening. Hasil yang diperoleh adalah memberikan layanan gratis kepada guru untuk screening kesehatan.

7) Penyuluhan dan pelatihan pengolahan sampah menjadi media tanam tanaman hias dilakukan 11dan 18 Agustus 2017. Tahapan yang dilakukan adalah pembuatan modul, persiapan alat dan bahan, sosialisasi, pengumpulan sampah yang bisa diolah, praktik lapangan. Hasil yang diperoleh adalah mengubah sampah menjadi barang yang bernilai jual tinggi dan melatih kreatifitas santriwati.

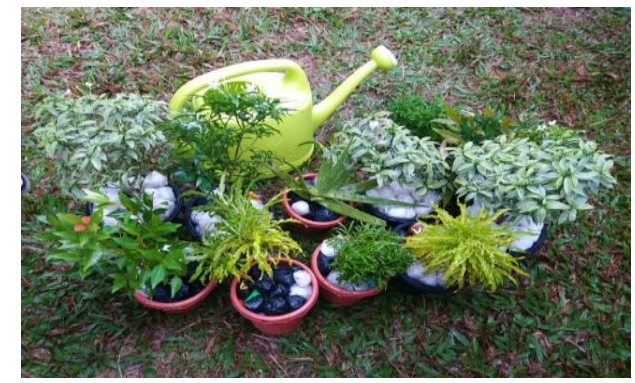

Gambar 20. Pemanfaatan Sampah plastik sebagai media tanam

8) Pelatihan Microsoft Office dan desain grafis dilakukan pada 9 s.d. 11 Agustus 2017. Tahapan yang dilakukan adalah pembuatan modul, sosialisasi, dan pelatihan. Hasil yang didapatkan adalah bertambahnya pengetahuan dan pelatihan kepada santriwati tentang aplikasi microsoft office dan peserta dapat mendesain spanduk, sticker dan pin.

\section{KESIMPULAN DAN SARAN}

\section{Kesimpulan}

Secara keseluruhan dapat disimpulkan hingga saat ini bahwa kegiatan PPM KKN Tematik KKN Pesantren dapat:

a. Meningkatkan kemampuan santri di pondok pesantren rekanan dalam bidang ilmu nonpesantren.

b. Munculnya ide kreatif dari mahasiswa dengan melihat keadaan berdasarkan ilmu yang mereka miliki.

c. Meningkatnya kesadaran hidup bersih, dan pentingnya teknologi yang berguna bagi santri pasca pesantren.

d. Pihak pondok pesantren antusias dengan kegiatan semacam ini dan berharap perlu dikembangkan dan berlanjut.

\section{Saran}

Adapun saran yang membangun dalam kegiatan ini yaitu agar ilmu dan produk yang telah diberikan kepada pondok pesantren dapat terus digunakan dan disebarluaskan untuk kepentingan yang bermanfaat. Selain itu, bagi mahasiswa dapat menjaga dan mengamalkan ilmu yang didapatkan dari pondok pesantren. 


\section{DAFTAR PUSTAKA}

Depdiknas, 2007, Kamus Besar Bahasa Indonesia. Jakarta: Balai Pustaka, Ed. III, Cet. III. Hamid, Abu, 1983. Sistem Pendidikan Madrasah dan Pesantren di Sulawesi Selatan, dalam Agama dan Perubahan Sosial, (ed) Taufiq Abdullah, Rajawali Press, Jakarta, hal. 328.

Madjid, Nurcholish, 1997, Bilik-Bilik Pesantren Sebuah Potret Perjalanan, Paramadina, Jakarta.

Mastuhu, 1988, Dinamika System Pendidikan Pesantren, INIS, Jakarta.

Mas'ud, Abdurrahman, 1998, "Why the Pesantren as Center for Islamic Studies Remains Unique and Stronger in Indonesia", makalah Seminar Internasional, Prince of songkla University Pattani. Lihat juga Ahmad Muthohar, A.R, Ideologi Pendidikan Pesantren "Pesantren ditengah Arus Ideologi-Ideologi Pendidikan", Rizki Putra, Semarang, hal. 12.

Munir dan Lily Zakiyah, 2011, Pesantren Harus Pertahankan Jati Dirinya, Wawancara Novriantoni dan Mohammad Guntur Romli dari Jaringan Islam Liberal (JIL) dengan Lily Zakiyah Munir, direktur Center for Pesantren and Democracy Studies (Cepdes), http://islamlib.com/lembaga/pesantren/lily-zakiyah-munir-pesantrenharus-pertahankan-jati-dirinya/, Diakses pada tanggal 6 April 2016.

Wahid, Abdurrahman, 1998, "Principles The Pesantren Education", dalam Manfred Oepen and Wolfgang Karcher (eds.), The Impact of Pesantren. P3M, Jakarta. Lihat juga Ahmad Muthohar, A.R, Ideologi Pendidikan Pesantren "Pesantren ditengah Arus Ideologi-Ideologi Pendidikan”, Rizki Putra, Semarang, hal. 12. 